peninsula, it is possible that much more remains. Cuite recently the gold fields of Madras have attracted a great deal of public interest, and a large amount of capital is being diverted to their exploration. For writing a history of British gold mining in India the time has not yet come, and we can only hope with Prof. Ball "that the actual results of this enterprise may come up to the high standard of success which has been predicted for it."

Amidst a variety of most interesting details as to the various gold diggings and gold workings in India, we select the following account of the Thibetan Gold Mines, which for many centuries and to the present day, send a reoular supply of gold to India.

"Of the very highest interest are the accounts of the Thibetan gold mines, which are given by the Pundits attached to the Indian Survey for the purpose of exploring countries north of the Himalayas. Unwittingly these admirable native servants of the Government of India have furnished facts which have enabled Sir Henry Rawlinson, and independently Prof. Frederic Schiern, Professor of History at the University of Copenhagen, to clear up a mystery which has been a puzzle to the historians and philosophers of many countries for upwards of 2000 years. A translation of Prof. Schiern's paper, ${ }^{\prime}$ by Anna M. H. Childers, will be found in the 'Indian Antiquary. ${ }^{2}$ It is a most remarkable example of learned research, and one very difficult to give in abstract. It is entitled 'The Tradition of the Gold-digging Ants.' But perhaps before giving the conclusions which Sir Henry Rawlinson and Prof. Schiern have arrived at, it will be best in this place to briefly describe the Pundits' observations :-

'During the expedition of 1867 the Pundit who had been at Lassa fell in at Thok Jalung, an important goldfield in the province of Nari Khorsam, with a large encampment of Thibetan miners, and took the opportunity to gain information relative to the working of the mines. In the third expedition, in 1868, another Pundit passed on as far as Rudok, at the north-west extremity of Chinese Thibet on the frontier of Ladak, and on his way back from Rudok visited the gold-fields of Thok Nianmo, Thok Sarlung, ${ }^{3}$, and Thok Jarlung. The map which accompanies Major Montgomery's narrative of the journeys of the Pundits gives in addition the gold-fields of Thok Munnak, Thok Ragyok, Thok Ragung, and Thok Dalung.' .... 'The miners' camp at Thok Jarlung, according to the measurements of the Pundits, is 16,300 feet above the sea-level.

'The cold is intense, and the miners in winter are thickly clad in furs.

'The miners do not merely remain under ground when at work, but their small black tents, which are made of a felt-like material, manufactured from the hair of the Yak, are set in a series of pits, with steps leading down to them ... seven or eight feet below the surface of the ground.' 'Spite of the cold the diggers prefer working in winter; and the number of their tents, which in summer amounts to 300 , rises to nearly 600 in winter. They prefer the winter, as the frozen soil then stands well, and is not likely to trouble them much by falling in.'

"They are occasionally attacked by bands of robbers, who carry off their gold.

"Sir Henry Rawlinson's remarks on these reports of the Pundits' researches and travels are as follows:4-

" "Now, then, for the first time, we have an explanation

${ }^{1}$ Verhand Kgl Danischen Gesellsch. der Wissensch. for 1870. Printed separately in Danish, German, and French.

2 Vol. iv. p. 225

3 Thok Sarlung had at one time been the chief gold-field of the district, Jarl had in a great measure been abandoned on the discovery of the Thok had been extracted." - Four. As. Snc., Bengal, vol, xxxix., Pt. 2, p. 53, had 8 .

Pall Mall Gazette, March 116,1869 , quoted in "Indian Antiquary,"
p. 225. of the circumstances under which so large a quantity of gold is, as is well known to be the case, exported to the west from Khoten, and finds its way into India from Thibet; and it is probable that the search for gold in this region has been going on from a very remote antiquity, since no one can read the ex-Pundit's account of Thibetan miners 'living in tents some seven or eight feet below the surface of the ground, and collecting the excavated earth in heaps previous to washing the gold out of the soil,' without being reminded of the description which Herodotus gives of the 'ants in the lands of the Indians bordering on Kaspatyrus (or Kashmir) which made their dwellings underground, and threw up sand heaps as they burrowed, the sand which they threw up being full of gold.'

"Prof. Schiern points out that the tradition was mentioned in writings of the middle ages, and those by Arabian authors It survived among the Turks. Strabo and Albertus Magnus treated the whole s! ory as a fiction. Xivrey supposed that the animals had become extinct owing to the auri sacra fames. Major Rennell supposed that the dwellers in mounds were termites or white ants. Humboldt's observations in Mexico on the habit of certain ants to carry about shining particles of hyalith was quoted by those who believed that the animals were really ants. Cther authorities suggested that they were marmots, jackals, foxes, or hyænas. Pliny having stated that horns of the Indian ant were preserved in the temple of Hercules at Erjthræ, Samuel Wähl, who maintained the hyæna theory, proved equal to the difficulty by suggesting that the horns might have been a lusus natura. Prof. Schiern ingeniously argued that the horns bad been taken from the skins of animals which formed the garments of the miners. It seems possible, however, that they were samples of the pickaxes made of sheep's horns, which, as is mentioned above, are used to the present day by the miners in Ladak.

"Prof. Schiern further points out that ancient writers say that the ants worked chiefly in winter, and connects this with the statement of the Pundit above quoted.

"In conclusion he writes:-

" 'For us the story partakes no longer of the marvellous. The gold-digging ants were originally neither real ants, as the ancients supposed, nor, as many eminent men of learning have supposed, larger animals mistaken for ants on account of their subterranean habits, but men of flesh and blood, and these men Thibetan miners, whose mode of life and dress were in the remotest antiquity exactly what they are at the present day."

The quotations that we have given will show the general reader what he may expect to find in this volume, in addition to the more scientific accounts of the several dian ond and gold mines.

(To be continued.)

\section{PRECIOUS CORAL}

WHILST preparing a set of lectures on Corals, Iately delivered at the Royal Institution, I made some inquiries as to the present state of the fisberies of precious coral from Messrs. Greck and Co., coral merchants, of Rathbone Place, who also have an establishment at Naples. They exhibited a very fine series of examples of raw and worked coral at one of my lectures, and also sent me the following short notes on the Italian and Sicilian coral fisheries, partly taken from an Italian newspaper, but which contain some facts which may be interesting to the readers of NATURE. I was shown a large number of the Sciacca specimens, all attached to groups of bivalve shells or pieces of dead coral. The blackened coral is described by Lacaze Duthiers in his famous monograph as "corail noirci dans la vase." It is very possible that the blackening substance is binoxide of mangarese, since we dredged, in deep water during the Challenger Expedi- 
tion, ldrge quantities of a dead coral skeleton, apparently allied to Corallium, which was blackened by that substance. It is in the hope of eliciting some definite information from the readers of NATURE concerning the so-called Japanese Corallium that I send the present notes. At a late meeting of the Zoological Society, Mr. G. O. Ridley, of the British Museum, read a paper on the Coraliidæ, and reviewed the species known, and exhibited specimens of the form said to come from Japan. I o'stained specimens of this corallium from Mr. Cutter, the London dealer, from whom I first learned that a precious coral was called Japanese. He told me that he had seen a large quaniity in the market in London, but that it would not fetch any price, whereas Messrs. Greck state that Japanese coral sold for an extremely high price in Italy. Messrs. Phillips, of Cockspur Street, who also exhibited a fine series of specimens of precious coral at one of my lectures, showed amongst them a carved jewel cut out of Japanese coral, which is remarkable as being of mixed colour, marbled white and red, and also, as they informed me, for its far greater hardness than ordinary precious coral.

Now although this coral, which is of a named species, is evidertly universally regarded in the trade as Japanese, all evidence available seems to prove that no precious coral occurs in Japan. The Challenger did not meet with any ; and though I inquired, I heard of none as dredged there. Moreover, in numerous Japanese illustrated works on the races of men, certain foreigners of some kind are represented as bearing in their hands precious coral as tribuie, or as the staple produce of their country, thus showing apparently that the coral is regarded as something rare from abroad in Japan. Perhaps, some of the correspondents of NATURE in Japan can state whether any corallium occurs in Japanese waters. H. N. MoSELEY

Extract from the letter of Messrs. Greck and Co.:-

"Coral fisheries on the coasts of Italy and Sicily begin about the middle of February, and continue till the middle of October. The value of the coral fished up varies im. mensely according to its colour and size; the pale pink is the most prized, especially if it be of a uniform colour throughout, without stains. Off Torre del Greco, near Naples, a large quantity of coral is found every year from 400 to 600 boats are sent out in search of it, each boat being of from six to ten tons' burden, with a crew of at least twelve men, and costing from 50ol. to $600 \%$ a boat Nearly all the inhabitants of Torre del Greco are employed by this industry, either as fishermen or in the manufacture of the coral brought to shore. The valuable pink coral is found chiefly off the coast of Sicily: in the year 1873 a bed was discovered in the Straits of Messina, in which the coral, though found only in small quantities and of a small size, was of immense value, owing to its beautiful pink, of a uniform colour, and without any of those stains which detract so much from its worth. The coral found in this place is sent chiefly to London and Birmingham; it is usually manufactured in the shape of 'lentils,' and in this form is largely used for rings, either set singly in half-hoops or surrounded by precious stones and pearls. Its value varies from $80 l$. to upwards of $200 \%$. per ounce.

"Unfortunately the supply of coral in this bed seems to have run short, and for the last few years coral-merchants have not found it worth their while to send boats in search of it. The last attempt was made last year by the firms of Criscuolo and Greck and Co., who despatched two boats with a crew of thirty selected men, but the find was so small as barely to pay the expenses of the outfit.

"This year out of 800 boats employed in the coral-fishery off the coast of Sicily, not one has been sent to the bed in the Straits of Messina. In I875 a local bed was discovered about twenty miles off the coast of Sciacca in Sicily, which was invaded for the next two years by 700 boats. This number of boats all crowded together in one spot, caused great confusion, and the Italian Government despatched a man of war to keep order among the fishermen. Another similar bed was discovered in 1878 , about ten miles further from the coast, and in 1880 yet another still further, to which 600 boats were sent, and we learn from the reports of the Custom House at Sciacca that in a few months about 8000 tons were fished, and although the quality of the coral is very inferior, being of a reddish colour and often quite black, its value is computed at several millions of pounds. The coral found off the coast of Sciacca does not grow as at other places attached to rocks, but is found clinging to any small object it can lay hold of, such as a shell, or a fragment of coral. It is supposed that its dark red or black colour is caused by the muddiness of the water in which it live;, although the depth of the sea at such spots is from 300 to 450 feet. This coral is not much esteemed in the English market, but is prepared in large quantities for the Indian market at Calcutta, by being exposed for months to the heat of the sun, and by being kept moist, when in time the black colour gradually disappears.

"A few years ago a large quantity' of Japanese coral found its way into the market at Naples, and fetched as much as 150 l. the kilo. in raw branches, in spite of its being a bad colour and somewhat cloudy. This high price was given on account of its extraordinary size. It is the largest real coral ever known. Nothing has been heard of it since, excepting that the fishery was prohibited in Japan."

\section{MAXIM'S SELF.ACTING FIRE- EXTINGUISHERS}

HOWEVER certain it is that fires in theatres will never be completely suppressed, we may still hope by energetic measures and systematic arrangements to lessen both their number and their danger, and it is scarcely probable that we shall ever again have to record such a catastrophe as that of the theatre at Nice or the Ring Theatre at Vienna. The preventive measures to be taken against a dangerous fre which may break forth at any moment are twofold-moral and material. The moral measures unfortunately do not admit of immediate or easy application. The public must be educated, and, as it were, familiarised with the danger, by being shown the precautions taken, the most direst escape available in case of fire, so as to avoid or rather diminish the terrible results due to the crush of a mass of frantic people precipitating themselves at the same moment into the outlets during the frightful struggle for life which accompanies the slightest panic. In short, the instinct" of selfpreservation must be so methodised as to be rendered most efficacious. Lamps, notices to indicate the way out, widening the passages and corridors, increasing the number of outlets and staircases, \&c., are all useful measures which are now being actively carried out.

In addition to these measures, whose special object is to lessen the number of victims, when it is impossible to stay the progress of the fire, there are others directed against the fire itself, by checking its advance, or strangling it, as it were, in its very birth. The stage is undoubtedly the most dangerous point, from the very nature of the materials composing it. With the decurations constantly exposed to blazing jets, it seems miraculous that accidents are not more frequent, and it is therefore upon the stage principally that the measures for fireextinction are to be brought to bear ; it is also important that they act instantly; for it is always more easy to obtain the mastery over a fire towards its commencement, before it has had time to develop into an incurable evil. The remedy, moreover, will of ten come too late, if its application depends on those who are on the stage, because they themselves, frequently under the influence of From La Nature. 